\title{
INSTITUT ROYAL DU PATRIMOINE ARTISTIQUE RADIOCARBON DATES XIV
}

\section{MICHELE DAUCHOT-DEHON and MARK VAN STRYDONCK}

Royal Institute of Cultural Heritage, B-1040 Brussels, Belgium

This list contains the results of ${ }^{14} \mathrm{C}$ determinations that we obtained in 1988 and $1989 . \delta^{13} \mathrm{C}$ was measured by the Free University, Brussels. Our dating techniques have been described previously (Dauchot-Dehon \& Heylen 1971; Dauchot-Dehon, Van Strydonck \& Heylen 1986).

\section{GeOLOGICAL SAMPLES}

\section{BELGIUM}

\section{Western coastal plain of Belgium series}

The following results complete the previously published series (Dauchot-Dehon \& Van Strydonck 1989) of peat from west Vlaanderen. Collected by L. Denys and submitted 1988 by C. Baeteman, Geological Service of Belgium (Baeteman 1989).

IRPA-826. Spoorweg 2.61

$$
1180 \pm 40
$$

$$
\delta^{13} \mathrm{C}=-25.1 \%
$$

Peat from the top of the upper layer, $2.61-2.68 \mathrm{~m}$ below surface, at Lampernisse $\left(51^{\circ} 03^{\prime} \mathrm{N}\right.$, $\left.2^{\circ} 47^{\prime} \mathrm{E}\right)$.

\section{IRPA-834. Spoorweg 6.09}

$\mathbf{5 8 5 0} \pm \mathbf{5 0}$

$$
\delta^{13} \mathrm{C}=-26.6 \%
$$

Peat from the top of an intercalated layer, $6.09-6.15 \mathrm{~m}$ below surface, at Lampernisse.

IRPA-848. Spoorweg 3.38

$4920 \pm 50$

$$
\delta^{13} \mathrm{C}=-26.1 \%
$$

Peat from the base of the upper layer, 3.38-3.45 m below surface, at Lampernisse.

IRPA-871. Spoorweg 6.45

$$
\begin{array}{r}
\mathbf{6 3 7 0} \pm \mathbf{6 0} \\
\delta^{13} C=-25.5 \% 0
\end{array}
$$

Peat from the base of the second layer, $6.45-6.50 \mathrm{~m}$ below surface, at Lampernisse.

\section{IRPA-927. Spoorweg 7.61}

$6670 \pm 60$

$$
\delta^{13} \mathrm{C}=-26.5 \%
$$

Peat from the top of the base layer, 7.61-7.70 $\mathrm{m}$ below surface, at Lampernisse.

IRPA-831. Orthodoxe kerk 6.95

$4240 \pm 60$

$\delta^{13} \mathrm{C}=-27.4 \%$

Peat from the base of an intercalated layer, $6.95-7.00 \mathrm{~m}$ below surface, at Pervijze $\left(51^{\circ} 03^{\prime} 20^{\prime \prime} \mathrm{N}\right.$, $\left.2^{\circ} 47^{\prime} 32^{\prime \prime} \mathrm{E}\right)$. 
IRPA-832. Orthodoxe kerk 2.52

Peat from the top of the upper layer, 2.52-2.57 m below surface, at Pervijze.

IRPA-833. Orthodoxe kerk 2.93

Peat from claying level in the upper layer, 2.93-2.98 m below surface, at Pervijze.

IRPA-847. Orthodoxe kerk 1.61

$2230 \pm 40$

$\delta^{13} \mathrm{C}=-27.3 \%$

Peat from the top of the upper layer, 1.61-1.68 m below surface, at Pervijze.

IRPA-846. Westende 3.90

$\mathbf{5 1 2 0} \pm \mathbf{5 0}$

$\delta^{13} \mathrm{C}=-26.5 \%$

Peat from the base of the upper layer, $3.90-3.95 \mathrm{~m}$ below surface, at Westende $\left(51^{\circ} 09^{\prime} 53^{\prime \prime} \mathrm{N}\right.$, $\left.2^{\circ} 46^{\prime} 47^{\prime \prime} \mathrm{E}\right)$.

IRPA-849. Vliegveld 5.59

$5960 \pm 60$

$\delta^{13} \mathrm{C}=-27.1 \%$

Peat from the second layer, $5.59-5.65 \mathrm{~m}$ below surface, at Leffinge $\left(51^{\circ} 10^{\prime} \mathrm{N}, 2^{\circ} 53^{\prime \prime} \mathrm{E}\right)$.

\section{IRPA-924. Vliegveld 5.17}

$\mathbf{5 5 4 0} \pm \mathbf{5 0}$

$\delta^{13} \mathrm{C}=-27.6 \%$

Peat from the base of the upper layer, 5.17-5.22 $\mathrm{m}$ below surface, at Leffinge.

General Comment (C.B.): Dates from the western coastal plain can be grouped into three series:

1. Basal peat

IRPA-927 - the base of the peat shows an age gradient in relation to the depth of the Pleistocene subsurface and the Holocene sea-level curve.

IRPA-871 - the top of the basal peat represents the time when the area became influenced by marine and/or coastal sedimentation.

2. Second regional peat layer

IRPA-831 - base; IRPA-834 - top; IRPA-849 - mean; the ages are concordant with each other as well as with previous dates (IRPA-612, Dauchot-Dehon \& Van Strydonck 1987: 197).

3. First regional peat layer or surface peat

IRPA-833 dates a marine intercalation in the surface peat. From previous dates, this intercalation shows a rather regional significance (IRPA-860, -727 and -527 in, respectively, Dauchot-Dehon \& Van Strydonck 1989: 189, 1987: 199; Dauchot-Dehon, Van Strydonck \& Heylen 1984: 386).

Top of peatlayer

IRPA-826, -832 and -847 - peat growth generally ended between 2700 and $2200 \mathrm{BP}$, and in more landward areas, between 1900 and 1600 BP. IRPA- 826 forms a striking exception; the date is probably too young because of modern rootlet contamination. IRPA-832 and -847 were taken from two different boreholes at a distance of only a few meters. Most probably, the top of the peat (IRPA-832) was partly eroded, although it was not apparent. 
Base of peat layer

IRPA-846, -848 and -924 - the results agree with expected dates, as the greatest number of samples from the base of the surface peat date between 4700 and $5220 \mathrm{BP}$.

\section{Noordzee series}

Shells from the North Sea, collected March 1988 by K. de Vos and submitted April 1988 by C. Baeteman. The sample was not big enough to pretreat with $1 \% \mathrm{HCl}$; it was cleaned with distilled $\mathrm{H}_{2} \mathrm{O}$ and scraped with a scalpel.

IRPA-896. TB333/400C

$1670 \pm 80$

$\delta^{13} \mathrm{C}=+1.1 \%$

Crystal structure determined by an X-ray: $100 \%$ aragonite. Diluted; $50.21 \%$ sample.

IRPA-897. TB333/400A

$6740 \pm 100$

$\delta^{13} \mathrm{C}=+0.1 \%$

Crystal structure determined by an X-ray: $100 \%$ aragonite. Diluted; $54.37 \%$ sample.

IRPA-898. TB326/280

$4870 \pm 70$

Crystal structure determined by an X-ray: $100 \%$ aragonite.

$\delta^{13} \mathrm{C}=-2.04 \% 0$

IRPA-899. TB409/100

$6840 \pm 80$

$\delta^{13} \mathrm{C}=-0.7 \%$

Crystal structure determined by an X-ray: $100 \%$ aragonite. Diluted; $87.92 \%$ sample.

\section{IRPA-900. TB409/165}

$6940 \pm 100$

$\delta^{13} \mathrm{C}=-0.9 \%$

Crystal structure determined by an X-ray: $90 \%$ aragonite, $10 \%$ calcite. Diluted; $56.50 \%$ sample.

General Comment (C.B.): Samples from Cardium edule shells and Spisula elliptica (IRPA-896) were taken from vibrocores drilled to determine the age of boundaries of the assumed subdivision, and hence, to establish a chronology of the Holocene deposits. No ${ }^{14} \mathrm{C}$ datings were carried out previously on these deposits, hence, no comparison can be made. However, according to the stratigraphical correlation of the boreholes, one must presume that the post-mortem effect of the shells is rather significant, and the age can only be regarded as maximum.

\section{Schelde series}

These samples complete the study of the Schelde River alluvial deposit (Dauchot-Dehon \& Van Strydonck 1987: 202; Dauchot-Dehon \& Van Strydonck 1989: 187-188) from Temse, Antwerpen $\left(51^{\circ} 06^{\prime} 50^{\prime \prime} \mathrm{N}, 4^{\circ} 11^{\prime} 28^{\prime \prime} \mathrm{E}\right)$. Collected and submitted 1988 by P. Kiden, University of Gent, Belgium.

IRPA-911. Tielrodebroek 1

Clayey peat from $2.65-2.78 \mathrm{~m}$ below surface.

IRPA-912. Tielrodebroek 2

Clayey peat from $2.98-3.16 \mathrm{~m}$ below surface.
$4220 \pm 50$

$\delta^{13} \mathrm{C}=-28.8 \%$

$\mathbf{5 0 7 0} \pm \mathbf{5 0}$

$\delta^{13} \mathrm{C}=-28.0 \%$ 
General Comment (P.K.): IRPA-911 and-912 date, respectively, top and base of a locally occurring organic clay layer, intercalated in the wood peat sequence of the lower Schelde alluvial plain. The large age difference between base and top of the clay layer, in comparison to its thickness (only $40 \mathrm{~cm}$ ), probably points to strong compaction of the organic clay during and after deposition, which is also comfirmed by lithostratigraphical cross-sections of the alluvial plain at the sampling point.

\section{IRPA-895. Assebroek}

$\mathbf{2 5 , 3 4 0 \pm 5 7 0}$

$\delta^{13} \mathrm{C}=-28.8 \%$ 。

Peat from Assebroek, Oost Vlaanderen $\left(51^{\circ} 11^{\prime} \mathrm{N}, 03^{\circ} 17^{\prime} \mathrm{E}\right)$. Collected and submitted 1988 by C. Verbruggen, University of Gent, Belgium.

\section{Walem Eekhoven series}

Organic material from a pleniglacial to Holocene stratigraphic sequence at Duffel, Antwerpen $\left(51^{\circ} 04^{\prime} 30^{\prime \prime} \mathrm{N}, 4^{\circ} 28^{\prime} \mathrm{E}\right)$. Collected Oct. 1988 and submitted Dec. 1988 by L. Huysmans, University of Antwerpen, Belgium.

IRPA-929. Duffel 1

$23,210 \pm 310$

$1.85 \mathrm{~m}$ below surface.

$\delta^{13} \mathrm{C}=-28.1 \%$ 。

IRPA-965. Duffel 2

$22,780 \pm 420$

$2.65 \mathrm{~m}$ below surface.

$\delta^{13} \mathrm{C}=-27.6 \%$ o

General Comment (L.H.): The Walem samples are from organogeneous layers, 3 and $5 \mathrm{~cm}$ thick, consisting of coarse plant remains, macroscopic twiglets and leaves, intercalated between fluvial and loamy sands of the infill of the Flemish valley. The samples were 165 and $85 \mathrm{~cm}$ above the Boom clay. Pollen and plant macrofossil analysis indicated tundra-type vegetation.

\section{NORWAY}

\section{Svalbard series}

Peat from Svalbard, Norway $\left(78^{\circ} 05^{\prime} \mathrm{N}, 21^{\circ} 00^{\prime} \mathrm{E}\right)$ collected Aug. 1987 and submitted March 1989 by L. Beyens, University of Antwerpen, Belgium. The samples were used to study the palaeoecology of diatoms and testate amoebae (Beyens \& Chardez 1987). Dates from the same valley are GrN-13,349: $3810 \pm 40 \mathrm{BP}$ and GrN-13,350: $4995 \pm 45 \mathrm{BP}$.

IRPA-928. Sample 1 RN III

Peat, $0-3 \mathrm{~cm}$ below surface. Diluted; $31.26 \%$ sample.

IRPA-991. Sample 2 RN III

Peat, $14-18 \mathrm{~cm}$ below surface. Diluted; $49.93 \%$ sample.

IRPA-992. Sample 3 RN III

Peat, 22-27 cm below surface. Diluted; $56.23 \%$ sample.

IRPA-993. Sample 4 RN III

Peat, $46-50 \mathrm{~cm}$ below surface. Diluted; $49.93 \%$ sample.

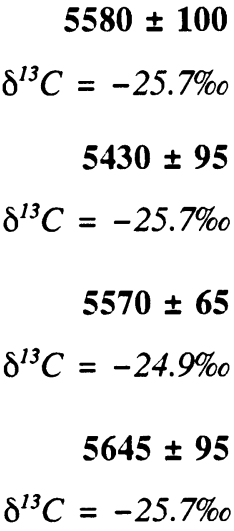


IRPA-994. Sample 5 RN IV

$7920 \pm 65$

Peat, $0-3 \mathrm{~cm}$ below surface.

$\delta^{13} \mathrm{C}=-24.4 \% 0$

IRPA-837. Sample 6 RN IV

$7710 \pm 60$

Peat, $33-36 \mathrm{~cm}$ below surface.

$\delta^{13} C=-26.2 \%$

IRPA-838. Sample 7 RN IV

$7920 \pm 80$

Peat, $56-59 \mathrm{~cm}$ below surface.

$\delta^{13} \mathrm{C}=-24.2 \%$

IRPA-995. Sample 8 RN IV

$10,980 \pm 145$

Peat, $84-88 \mathrm{~cm}$ below surface.

$\delta^{13} C=-27.5 \%$

General Comment (L.B.): The ${ }^{14} \mathrm{C}$ series indicates a disturbed environment; probably the peat layers were exposed to erosion by the river. However, the preliminary results of the rhizopod analysis show some biostratigraphical zonation, related to the hydrological conditions at the bog surface. Interesting is the result of IRPA-995. It confirms the existence of ice-free areas where moss vegetation could exist as early as $\sim 11,000 \mathrm{BP}$.

\section{BANGLADESH}

Dakha series

Samples from Dhaka, Bangladesh $\left(23^{\circ} 45^{\prime} \mathrm{N}, 90^{\circ} 24^{\prime} \mathrm{E}\right)$ collected March 1987 by M. D. Hussain Monsur and submitted by C. Baeteman.

IRPA-977. P1

$4040 \pm 80$

Wood found in greenish silty clay, Layer 4 in Gulshan Lake.

$\delta^{13} \mathrm{C}=-28.0 \%$

IRPA-978. P4

$4910 \pm 70$

Wood found in peaty mud under P1.

$\delta^{13} \mathrm{C}=-28.9 \%$

IRPA-979. P5

$5730 \pm 60$

Wood taken from Gulshan Lake in the lower sandy Layer 2.

$\delta^{13} C=-27.4 \% \circ$

IRPA-980. P7

$8940 \pm 100$

Wood found in a gravelly bed under P5.

$\delta^{13} \mathrm{C}=-27.0 \%$

IRPA-981. P8

$4830 \pm 70$

$\delta^{13} \mathrm{C}=-29 \%$

Wood found in the top clay layer, below the soil horizon, in the eastern part of Dhaka city.

IRPA-982. P9

$12,780 \pm 140$

$\delta^{13} \mathrm{C}=-29.7 \%$

Wood found in the Kalibari pond of east Dhaka city. It was embedded in a sandy layer overlain by a red bed. 
General Comment (H.M.): This series was collected in the Madhupur area of Dakha city. Samples of reworked wood in floodplain deposits were collected, as no other in-situ, datable organic material was available. The wood fragments, however, accumulated synchronously with the sediments at the different stratigraphic levels. Thus, these are maximum ages. The fragments indicate that they were deposited by one cycle of transportation. No other age determinations were carried out previously in these deposits; hence, no comparison nor calibration can be made. The ${ }^{14} \mathrm{C}$ dates, however, enabled us to establish a provisional stratigraphic subdivision of the Holocene floodplain deposits (Hussain Monsur 1990).

\section{ARCHAEOLOGICAL SAMPLES}

\section{BELGIUM}

IRPA-839. KU86-70

$770 \pm 60$

$\delta^{13} \mathrm{C}=-29.1 \% 0$

Wood from a beam at Kuringen, Limburg $\left(50^{\circ} 56^{\prime} 45^{\prime \prime} \mathrm{N}, 5^{\circ} 18^{\prime} 34^{\prime \prime} \mathrm{E}\right)$. Collected and submitted 1987 by L. van Impe, National Service Excavations, Belgium. The result was used to date the oldest building phase of Prinsenhof mound.

\section{Wijshagen series}

Charcoal from Tumulus E at Meeuwen-Gruitrode, Limburg $\left(51^{\circ} 60^{\prime} 22^{\prime \prime} \mathrm{N}, 5^{\circ} 33^{\prime} 16^{\prime \prime} \mathrm{E}\right)$, collected and submitted 1987 by L. van Impe. Expected age: 5th century BC.

IRPA-840. 87WH348

Sample from Tomb 37.

IRPA-841. 87WH326

Sample from Tomb 33.

IRPA-842. 87WH570

Sample from Tomb 43.

IRPA-843. 87WH529

Sample from a bronze urn.

IRPA-844. 87WH545

Sample from a funeral pile.
$2160 \pm 50$

$\delta^{13} \mathrm{C}=-25.4 \%$ 。

$2025 \pm 60$

$\delta^{13} C=-24.9 \%$

$2245 \pm 60$

$\delta^{13} C=-25.2 \% 0$

$2320 \pm 60$

$\delta^{13} \mathrm{C}=-25.1 \%$

$2300 \pm 50$

$\delta^{13} C=-25.9 \%$

General Comment (L.v.I.): This was an archaeological investigation of a group of burial mounds, covering cremation graves with Bronze-Age cists and situlae, and also of a group of poor cremation graves. IRPA- 843 (charcoal from Situla E) and -844 (charcoal from a surrounding pyre) average $2308 \pm 42$. A $2 \sigma$ calibration gives $69 \%$ probability for a date between cal BC 428 and 351 .

A date for the burial beneath Mound E, at the end of the 5th or in the first half of the 4th century $\mathrm{BC}$, agrees very well with the youngest archaeological features found in the grave. An ash container dates to a preceding period, and may be considered a "family piece." IRPA-840, -841 and -842 (charcoal from three poor cremation graves, found in the area) suggest a date in the following 
phase of occupation. A link between the rich mounds with situlae and the group of poor burials, reflecting social differences, cannot be established.

\section{Gouvernementstraat series}

Samples from Gent, Oost Vlaanderen $\left(51^{\circ} 03^{\prime} \mathrm{N}, 03^{\circ} 44^{\prime} \mathrm{E}\right)$. Since 1987, Dienst Monumentenzorg en Stadsarcheologie has excavated a site between Borreputsteeg and Gouvernementstraat at Gent. The results are important for dating the origin of the city. Collected and submitted Jan. 1988 by M. C. Laleman, Dienst Monumentenzorg en Stadsarcheologie.

IRPA-902. G2

$$
24,100 \pm 1200
$$

Organic material from Level E, Layer 3. $\delta^{13} \mathrm{C}=-29.0 \%$

IRPA-904. G4

$1230 \pm 40$

Organic material from Level L, Layer 2.

$\delta^{13} \mathrm{C}=-24.5 \%$

IRPA-905. G5

$1000 \pm 30$

Organic material from Level $\mathrm{H}$.

$\delta^{13} \mathrm{C}=-28.6 \%$

IRPA-906. G6

$980 \pm 40$

Organic material from Level $\mathrm{H}$.

$\delta^{13} \mathrm{C}=-27.8 \% 0$

\section{Werken series}

Samples from excavation of Hoge Andjoen mound at Werkem, Kortemark, west Vlaanderen $\left(51^{\circ}\right.$ $1^{\prime} 43^{\prime \prime} \mathrm{N}, 2^{\circ} 57^{\prime} 50^{\prime \prime} \mathrm{E}$ ). Collected and submitted 1988 and 1989 by C. Vanthournout, Gemeentebestuur, Kortemark Belgium (Meulemeester \& Vanthournout 1986).

IRPA-913. 87WO3(31A)

Wood (Quercus), 13 rings. We do not suspect the old wood effect.

IRPA-914. 88WO1(78)

Wood (Quercus) from the fill of a pit.

IRPA-915. 87WO3(51)

Wood (Quercus), 18 rings. The exterior was used for dating.

IRPA-916. 87WO3(52)

Wood (Quercus), 29 heartwood rings.

IRPA-917. 87WO3(31B)

Wood (Quercus), 13 rings. We do not suspect the old wood effect.
$1190 \pm 30$

$\delta^{13} \mathrm{C}=-25.0 \% 0$

$1140 \pm 40$

$\delta^{13} C=-25.3 \% \circ$

$1100 \pm 40$

$\delta^{13} C=-24.7 \% \circ$

$1090 \pm 35$

$\delta^{13} \mathrm{C}=-25.5 \% 0$

$1040 \pm 30$

$\delta^{13} \mathrm{C}=-26.2 \% 0$

General Comment (C.V.): The dates indicate a very short duration of occupation. The floruit covers a period of only 100 years (cal AD 860-960) (Ottaway 1973). The results give no information about the use of the Hoge Andjoen as a whole, because samples of only three levels were 
collected. These levels yield dates that form a very coherent series with a spread of only 150 years. The construction of the mound from Floor 2 to Floor 6 occurred in a relatively short time, probably one century (cal AD 860-960). However, it is possible that the dated material was not in situ.

\section{Onze-Lieve-Vrouw Cathedral Antwerpen series}

Samples from Onze-Lieve-Vrouw Cathedral at Antwerpen $\left(51^{\circ} 13^{\prime} 16^{\prime \prime} \mathrm{N}, 4^{\circ} 23^{\prime} 60^{\prime \prime} \mathrm{E}\right)$. Collected Sept. 1987 by M. Van Strydonck and submitted Sept. 1987 by T. Oost, Oudheidkundige Musea, Antwerpen.

IRPA-854. AK-14

$710 \pm 200$

Wood from upper Layer 14; North Choir. Diluted; $13.6 \%$ sample.

$\delta^{13} C=-28.1 \%$ 。

IRPA-855. AK-11

$800 \pm 60$

Charcoal from calcareous Layer 17; North Choir. Diluted; $54.01 \%$ sample. $\quad \delta^{13} \mathrm{C}=-26.3 \%$

IRPA-856. AK-13

$760 \pm 50$

Charcoal from Layer 17; North Choir.

$\delta^{13} \mathrm{C}=-27.3 \%$

IRPA-948. AK-3

$940 \pm 40$

Charcoal from under a Roman wall.

$\delta^{13} \mathrm{C}=-27.0 \%$ o

IRPA-967. AK-6

$980 \pm 30$

Twigs from a well.

$\delta^{13} C=-28.8 \% 0$

IRPA-972. AK-10

$790 \pm 30$

Wood from Wall T; North Choir.

$\delta^{13} \mathrm{C}=-26.5 \%$

General Comment (M.V.S.): Samples were dated to determine different construction phases. Ak-3 and AK- 6 represented one construction phase, Samples AK-10,11, 13 and 14 a younger construction phase. (Van Strydonck, M., Some examples of the use of the Floruit to estimate the duration of archaeological events: Time and environment, ms. in preparation; Van Strydonck, van der Borg \& de Jong 1992).

\section{Kooigem series}

Samples from the excavation of Kooigem bos at Kortrijk $\left(50^{\circ} 44^{\prime} 45^{\prime \prime} \mathrm{N}, 0^{\circ} 21^{\prime} \mathrm{E}\right)$. Collected and submitted 1989 by J. Termote, Vereninging voor Oudheidkundige Bodemonderzoek, west Vlaanderen (Termote 1987). Another date for the same site is IRPA-802: $2300 \pm 60$ BP (DauchotDehon \& Van Strydonck 1989).

IRPA-918. K3 88/20 A

$2350 \pm 60$

Charcoal from the fill of a channel.

$\delta^{13} \mathrm{C}=-25.8 \%$

IRPA-919. K3 88/20 B

$2330 \pm 60$

Charcoal from the soil of a channel.

$\delta^{13} \mathrm{C}=-26.9 \%$ 


\section{IRPA-990. K3 88/20 K2}

$2260 \pm 60$

Charcoal from the fill of a grain warehouse.

$\delta^{13} \mathrm{C}=-26.1 \%$

\section{Burchtgracht series}

Samples from the Burchtgracht excavation at Antwerpen ( $\left.51^{\circ} 13^{\prime} 16^{\prime \prime} \mathrm{N}, 4^{\circ} 23^{\prime} 60^{\prime \prime} \mathrm{E}\right)$. Submitted Aug. 1988 by C. Warmenbol, Antwerpse Vereninging voor bodem en grotonderzoek. Expected age: AD 1200-1500.

IRPA-921.A

$680 \pm 40$

Wood (Quercus) from a pile of the first arch of the sluice system.

$\delta^{13} \mathrm{C}=-24.9 \%$

IRPA-922.B

$650 \pm 30$

Wood (Abies) from a pile of the second arch of the sluice system.

$\delta^{13} \mathrm{C}=-26.2 \%$

IRPA-923.C

$640 \pm 50$

Wood (Quercus) from the fill of a channel.

$\delta^{13} \mathrm{C}=-25.6 \%$

Comment (M.V.S.): Dates construction of the town wall.

\section{Maldegem series}

The following results complete the previously published series (Dauchot-Dehon \& Van Strydonck 1989 ) of wood from Roman wells at Maldegem, Oost Vlaanderen $\left(51^{\circ} 13^{\prime} 22^{\prime \prime} \mathrm{N}, 3^{\circ} 25^{\prime} 38^{\prime \prime} \mathrm{E}\right)$. Collected and submitted 1989 by H. Thoen, University of Gent, Belgium (Thoen \& Vandermoere 1986).

IRPA-970. MAV 88/7/k-f

$1770 \pm 50$

Branches of wood (Alnus, Fraxinus) from Well 4.

$\delta^{13} \mathrm{C}=-27.6 \%$

IRPA-971. MAV 88/7/k-w2

$1870 \pm 50$

Board of wood (Alnus) from Well 4.

$\delta^{13} C=-29.1 \% 0$

IRPA-845. MAV 85/2/D1/N1

$1870 \pm 30$

Wood (Alnus) from Well 1.

$\delta^{13} \mathrm{C}=-28.4 \%$

General Comment (H.T.): Samples are from a Roman fortified site at Maldegem-Vake, ca. AD 175-200. They are waterlogged wood from Wells 1 (IRPA-845) and 4 (IRPA-970, -971). IRPA970 and -971 agree with the archaeological date. In order to solve the problem of IRPA-673 (Dauchot-Dehon \& Van Strydonck 1989: 191), which was too young (1630 $\pm 50 \mathrm{BP}$ ), a new sample, IRPA-845, was dated twice. The new result agrees better with the archaeological date and the averaged radiocarbon date of the previously dated samples.

\section{IRPA-879. Abdij'T Park}

$305 \pm 60$

$\delta^{13} \mathrm{C}=-25.9 \%$

Straw from plaster of a building, Abdij van het Park, at Heverlee, Brabant $\left(50^{\circ} 52^{\prime} \mathrm{N}, 04^{\circ} 42^{\prime} \mathrm{E}\right)$. 
Collected 1988 by K. Bos and submitted 1986 by R. M. Lemaire, University of Leuven, Belgium. Result agrees with archaeological data.

\section{IRPA-910. Hoge weg}

$2430 \pm 60$

Organic material from a pile. The result completes a previously published series (Dauchot-Dehon \& Van Strydonck 1989: 187-200) from the Hoge weg site at Gent, Oost Vlaanderen (51 ${ }^{\circ}{ }^{\prime} \mathrm{N}$, $4^{\circ} 47^{\prime}$ E). Collected 1988 by M. Van Strydonck and submitted July 1988 by M. C. Laleman.

\section{IRPA-920. L'abri de la Sigillée}

$4460 \pm 60$

$\delta^{13} \mathrm{C}=-19.6 \%$

Human bones from a collective sepulture at Bomal/Ourthe, Luxembourg $\left(50^{\circ} 22^{\prime} 31^{\prime \prime} \mathrm{N}, 5^{\circ} 32^{\prime} 29^{\prime \prime} \mathrm{E}\right)$. Collected 1978 and 1986 by J. Dubois and L. Hendrickx and submitted Aug. 1988 by F. Hubert, National Service Excavation, Belgium (Hendrickx \& Dubois 1988).

IRPA-932. Saint Sauveur

$1230 \pm 40$

$\delta^{13} \mathrm{C}=-28.8 \% 0$

Charcoal from Saint Sauveur, Hainaut $\left(50^{\circ} 42^{\prime} 46^{\prime \prime} \mathrm{N}, 3^{\circ} 36^{\prime} 53^{\prime \prime} \mathrm{E}\right)$. Collected April 1988 and submitted Nov. 1988 by Ph. Crombé, Geschied en Oudheidkundige kring van Ronse.

\section{TURKEY}

\section{Pessinus series}

Samples from excavations of the Pessinus Acropolis at Ballihisar, Turkey $\left(39^{\circ} 20^{\prime} \mathrm{N}, 31^{\circ} 35^{\prime} \mathrm{E}\right)$. Submitted Dec. 1988 by J. Devreker, University of Gent, Belgium.

$$
\text { IRPA-930. 88/1/4 (38-6) }
$$

$1930 \pm 30$

Wood from Tomb 38. A Roman age was expected.

$$
\begin{array}{r}
\delta^{13} C=-23.6 \% 0 \\
1410 \pm 40 \\
\delta^{13} C=-24.7 \% 0 \\
1960 \pm 30 \\
\delta^{13} C=-23.0 \% 0 \\
1860 \pm 40 \\
\delta^{13} C=-25.6 \% 0
\end{array}
$$

Charcoal from Well 60. A Byzantine age was expected.

IRPA-940. 89/1/5 55

Charcoal from Layer 5 .

IRPA-941. 89/1/5 33

Charcoal from Layer 4.

\section{BALEARIC ISLANDS}

\section{Mallorca series}

Samples from Mallorca, Spain $\left(39^{\circ} 34^{\prime} \mathrm{N}, 2^{\circ} 44^{\prime} \mathrm{E}\right)$, collected and submitted $1988-1989$ by W. Waldren, Deya Archaeological Museum and Research Center, Deya Mallorca, Spain.

\section{IRPA-835. ABSM}

$3700 \pm 60$

Charcoal from a Level C enclosure, Pre-talayotic period.

$$
\delta^{13} \mathrm{C}=-24 \% 0
$$


IRPA-836. SMSS

Bone from the Post-talayotic period.

$2500 \pm 40$

IRPA-880. SFO 84109

$\delta^{13} \mathrm{C}=-19.6 \%$

Charcoal from Site SFO YS T4, Phase IV.

$2680 \pm 60$

IRPA-881.SFO 84115

$\delta^{13} \mathrm{C}=-22.4 \%$

Charcoal from Site SFO YS T4, Phase III.

$$
2580 \pm 60
$$

$\delta^{13} \mathrm{C}=-23.8 \% 0$

IRPA-885. SFO YS HH

$2100 \pm 60$

$\delta^{13} \mathrm{C}=-23.3 \% 0$

Charcoal from $0-80 \mathrm{~cm}$ depth, in survey Trench WW inside a wall of a hut south of Trench HH.

IRPA-886. SFO YS T2

$680 \pm 50$

Charcoal from the entrance floor.

$\delta^{13} \mathrm{C}=-24.2 \%$

IRPA-888. SFO-OS/OSW

$1530 \pm 50$

Charcoal from Level QD13.

$\delta^{13} C=-24.9 \%$

IRPA-889. SFO-OS/EW

$110 \pm 40$

Charcoal from Level Q154. Diluted; $52.6 \%$ sample.

$\delta^{13} C=-24.5 \%$

IRPA-892. SFO-OS/WWE

$185 \pm 40$

Charcoal from Level QC18.

$\delta^{13} \mathrm{C}=-24.1 \%$

IRPA-893.SFO-OS/SW

$1600 \pm 50$

Charcoal from Level QAO.

$\delta^{13} \mathrm{C}=-23.8 \%$

IRPA-907. SFO YS T4

$2815 \pm 60$

Charcoal from Phase I.

$$
\delta^{13} \mathrm{C}=-23 \%
$$

IRPA-908. Sample \#1

$3570 \pm 70$

Charcoal from Level III 8. Diluted; $73.34 \%$ sample.

$\delta^{13} \mathrm{C}=-25.2 \%$

IRPA-909. Sample \#2

$$
3580 \pm 60
$$

Charcoal from Level III 9.

$\delta^{13} \mathrm{C}=-25.0 \%$

IRPA-976. Sample \#4

$2960 \pm 60$

Charcoal from Quadrant N7-2, Level II. Talayotic period.

$\delta^{13} \mathrm{C}=-20.5 \%$

General Comment (W.W.): Dates agree with archaeological estimates (Waldren 1991). 


\section{ECUADOR}

IRPA-812. Z3B3-001-107 MC-001

$2080 \pm 60$

$\delta^{13} \mathrm{C}=-25 \%$ o

Charcoal from a pit at Cumbaya, Ecuador $\left(0^{\circ} 11^{\prime 2} 23^{\prime \prime} \mathrm{S}, 78^{\circ} 26^{\prime} 09^{\prime \prime} \mathrm{W}\right)$. Collected Oct. 1987 and submitted July 1987 by J. Buys, Ambabel, Quito, Ecuador. Diluted; $71.1 \%$ sample. Expected age: 500 BC-AD 1500.

\section{REFERENCES}

Baeteman, C. 1989 Quaternary sea-level investigations from Belgium. Belgium Geological Service Professional Paper 1989/6(241): 59-91.

Beyens, L. and Chardez, D. 1987 Evidence from testate amoebae for changes in some local hydrological conditions between 5,000 BP and 3,800 BP on Edgeøya (Svalbard). Polar Researcher 5(5): 165-169.

Dauchot-Dehon, M. and Heylen, J. 1971 Institut Royal du Patrimoine Artistique radiocarbon dates II. Radiocarbon 13(1): 29-31.

Dauchot-Dehon, M. and Strydonck, M. Van 1989 Institut Royal du Patrimoine Artistique radiocarbon dates XIII. Radiocarbon 31(2): 187-200.

1987 Institut Royal du Patrimoine Artistique radiocarbon dates XII. Radiocarbon 29(2): 197-208.

Dauchot-Dehon, M., Strydonck, M. Van and Heylen, J. 1984 Institut Royal du Patrimoine Artistique radiocarbon dates X. Radiocarbon 26(3): 384-391.

1986 Institut Royal du Patrimoine Artistique radiocarbon dates XI. Radiocarbon 28(1): 69-77.

Henderickx, L. and Dubois, J. 1988 L'abri de la Sigillée à Juzaine-Bomal (Province de Luxembourg). Revue d'Archéologie et de Paléontologie 5: 7-19.

Hussain Monsur, M. D. (ms.) 1990 Stratigraphical and paleomagnetical studies of some Quaternary deposits of the Bengal Basin, Bangladesh. Ph.D. thesis, Vrije University, Brussels: 241 p.

Meulemeester, J. de and Vanthournout, C. 1986 De "Hoge Andjoen"-motte te Werken. Archaeologica Belgica II(1): 105-108.

Ottaway, B. 1973 Dispersion diagrams: A new approach to the display of carbon-14. Archaeometry 15(1): 5-12.

Strydonck, M. J. Y. Van, van der Borg, K. and De Jong, A. F. M. 1992 Radiocarbon dating of lime and organic material from buildings. In Long, A. and Kra, R. S., eds., Proceedings of the 14 th International ${ }^{14} \mathrm{C}$ Conference. Radiocarbon 34(3): in press.

Termote, J. 1987 De Keltische hoogtenederzetting van Kooigem bos, de opgravingscampagne 1986. Westvlaamse Archaeologica 3(2): 61-72.

Thoen, H. 1988 The Roman fortified Site at Maldegem, 1986 Excavation Report. Scholae Archaeologicae 9: 5-78.

Thoen, H. and Vandermoere, N. 1986 The Roman fortified Site at Maldegem, 1985 Excavation Report. Scholae Archaeologicae 6: 5-58.

Waldren, W. 1991 Age determination, chronology and radiocarbon recalibration in the Balearic Islands.In Proceedings of the 2nd Deya International Conference of Prehistory. Tempus Reparatum. BAR International Series 574: 45-57. 